\title{
HVAD ER HISTORISME?
}

I den europæiske idéhistorie anvendes termen „historisme“ ofte til beskrivelse af en bestemt ændring i historisk bevidsthed, der forekom mellem Oplysningen og vores samtid og med Tyskland som sit centrum. Der er imidlertid langt fra enighed om dette begrebs betydning samt om hvilke historiske fænomener og idéer, det refererer til. I denne artikel ønsker jeg at bidrage til begrebets klargøring. Til dette formål vil jeg opstille tre overordnede kategorier, som jeg mener, dets betydnings- og anvendelseshistorie kan indordnes under:

(1) historismen som et produkt af det attende århundredes klassicisme og historiefilosofi, (2) historisme som politisk historieskrivning og som en intellektuel refleksion af politiske og sociale forhold i det nittende århundrede og sluttelig (3) historisme som historieskrivningens videnskabeliggørelse. Disse

kategorier er analytiske generaliseringer, og overlapper i de fleste konkrete analyser af historismen hinanden. Et af de tre synspunkter vil dog typisk være fremherskende og præge det generelle analytiske blik. Derfor mener jeg, at mine sondringer bidrager til forståelsen af et begreb, der stadig hyppigt optræder inden for en lang række humanistiske og samfundsvidenskabelige discipliner.

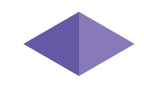

D en tyske historiker Friedrich Meinecke beskriver i 1936 det videnskabelige og åndshistoriske fænomen „historisme“ (Historismus) som „eine der grössten geistigen Revolutionen, die das abendländische Denken erlebt hat“, og videre som „die höchste bisher erreichte Stufe in dem Verständnis menschlicher Dinge“. ${ }^{1}$ I en ikke mindre vidtløftig men i sin vurdering dog diametralt modsat betragtning hævdes det sytten år senere af den tysk-amerikanske filosof Leo Strauss, at „[h]istoricism culminated in nihilism.“2 På den ene side står historis- 
men for fremskridtet og frigørelsen, på den anden for en undergravning af værdier og en sejrende irrationalitet.

Denne undersøgelse af historismen er ansporet af den betragtning, at en idé, der på denne måde kan påkalde sig så stærkt følte og så radikalt forskelligartede holdninger, og som hos fremtrædende tænkere er blevet tilskrevet så skæbnesvangre følgevirkninger, gør krav på interesse og opmærksomhed. Selv et kursorisk blik på historismebegrebets betydnings- og anvendelseshistorie blotlægger, at det besidder en flertydighed, som kun få andre begreber, der ikke er af eksplicit politisk karakter, formår. Jeg vil forsøge i denne artikel at indkredse de overordnede idéhistoriske fænomener, som historismebegrebet igennem tiden har tilsigtet, og herigennem forsøge at skabe overblik over den hidtidige historismereception. Sat på kortform vil jeg forsøge at besvare spørgsmålet: hvilke grundlæggende betydningsvariationer kan der identificeres i brugen af historismebegrebet? Med dette spørgsmål fjerner jeg i hovedsagen blikket fra langt størstedelen af den kanon af tænkere, som begrebet identificeres med. Dette skyldes, at historismen, som så mange andre periodebetegnelser, har det karaktertræk, at det næsten aldrig var anvendt til selvbeskrivelse af de tænkere, der i tilbageblik beskrives som hørende til perioden. Enkelte undtagelser lader sig anføre, som Friedrich Meinecke for historien og Ulrich von Wilamowitz-Moellendorff for filologien. Givet denne status for begrebet er jeg altså, foruden sådanne sporadiske undtagelser, først og fremmest henvist til den sekundære litteratur.

For analytisk at reducere begrebets kompleksitet, har jeg inddelt dets betydningsnuancer efter tre kategorier, som jeg mener indfanger de overordnede variationer. Den første kategori angår det perspektiv på historismen, der finder traditionens grundlæggende karaktertræk i historiefilosofiske og klassicistiske idéer, der blev formuleret allerede i det 18. århundrede. Den næste omfatter de undersøgelser af historismen, der ser den i krydsfeltet mellem historieskrivning og politik. Den sidste omhandler videnskabeliggørelsen af historieskrivningen samt de stilistiske og retoriske udviklinger i tekstfremstillingen, dette medfulgte.

Opdelingen skal ikke forstås sådan, at hver historismeforsker eller hver monografi kan placeres entydigt indenfor én af disse kategorier. Som oftest vil en blanding kunne findes, men med en perspektivisk vægtning ved enten historismens teoretisk-filosofiske grundlag, dens forhold til samfundet eller dens videnskabshistoriske karakter. Jeg ønsker med mine kategorier at opdele idéerne om historismen, ikke de tænkere eller værker, der taler om historismen.

For tilstrækkeligt at klargøre genstandsfeltet for mine analyser, må der på forhånd anstilles nogle yderligere afgrænsninger og anføres nogle generelle enighedspunkter, der kan findes i dette ellers så omstridte område. 


\section{Indkredsning af genstandsfeltet}

En grundlæggende begrænsning, jeg vil gøre mig i denne artikel, er at udelukke den anvendelse af begrebet historisme, som først og fremmest associeres med Karl Popper. Denne anvendelse finder i begrebet en formal og polemisk kategori, der fra udgangspunktet er pejorativt ladet. For denne betydning vil man ofte på dansk og tysk se begrebsversionen med den ekstra stavelse anvendt: ,historicisme/Historizismus“. ${ }^{3}$ Ydermere ønsker jeg ikke at undersøge den betydning, man kan finde af begrebet i videnskabsteoretiske tekster, hvor historisme, lig Poppers historicisme, ikke refererer til nogen historisk tradition, men snarere beskriver et analytisk perspektiv, der i sig selv ikke nødvendigvis har nogen forbindelse til de tyske historistiske tænkeres fremgangsmåder. In summa vil jeg beskæftige mig med historismen som en deskriptiv betegnelse og som et samlebegreb for en intellektuel tradition udspringende i den tysktalende verden.

Et væsentligt og ofte citeret forsøg på at indholdsbestemme denne tradition kan findes hos teologen Ernst Troeltsch, der ofte betragtes som den første til at bruge historismebegrebet på en systematisk facon. Troeltsch bestemmer historismen som „die grundsätzliche Historisierung unseres Wissens und Denkens“. 4 Han peger her på det mest generelle betydningselement i historismebegrebet, der kan tjene som minimumsdefinition, nemlig en hidtil uset opfattelse af historisk kontingens som vilkår for mennesket og samfundet.

En periodisering, der ofte tages i anvendelse fra videnskabshistorisk hold, afgrænser historismen tidsligt ved at kontrastere den til tidligere og senere paradigmer i historieskrivningen. Således beskriver historieteoretikeren Jörn Rüsen historismen som den „die zweite Grossepoche“ i moderne historieskrivnings historie, der tæller oplysning, historisme og „moderne historievidenskab“ (hvor fremvæksten af socialhistorie og kulturhistorie definerer sidstnævnte). ${ }^{5} \mathrm{Om}$ man accepterer sådanne epokale snit eller ej, peger Rüsens definition på flere væsentlige elementer, med hvilke historismen kan placeres på en idéhistorisk tidslinje. For det første forstås den som en reaktion mod (dele af) oplysningstiden og et bevidst opgør med flere af oplysningshistorieskrivningens grundprincipper. Dernæst anses den som en intellektuel tradition, der ikke ubrudt flyder over i vores

3 Popper var sig selv bevidst, at han anvendte termen anderledes end hovedstrømningen i historismeforskningen. Derfor arbejdede Popper også med sondringen mellem „historicism“ og „historism“, en sondring, som siden flød sammen i engelsksprogede kontekster (hvor begge betydninger blev indføjet under „historicism“). På dansk og tysk består skellet stadig mellem historisme/Historismus og historicisme/Historizismus, hvor førstnævnte betegner den tyske tradition og sidste et polemisk begreb.

4 Troeltsch 1922, s. 102.

5 Rüsen 1993, s. 18. Et fremtrædende eksempel på den moderne historieskrivning kan findes hos historikere som Hans Ulrich Wehler og Jürgen Kocka, der i eksplicitte opgør med historismen udviklede socialhistoriske og samfundsanalytiske teorier og metoder for historieforskningen, som de mente tog højde for de dimensioner af historien, som historismen havde negligeret. 
samtid. Ganske vist kan nutidig historieskrivning ikke, som Rüsen understreger, entydigt bestemmes som „nachhistoristisch“, men en markant overgang, hvor mange af dens egne principper og grundtanker blev problematiseret, betragtes som havende fundet sted i første halvdel af det 20. århundrede. ${ }^{6}$

Disse helt overordnede perspektiver, hvormed jeg her indledningsvist har forsøgt at fremstille en stabil betydningskerne i historismebegrebet, siger imidlertid meget lidt om, hvilket konkret indhold, der definerer en tænker, et værk eller en idé som hørende til den historistiske tradition. Af sådanne indholdsmæssige bestemmelser mener jeg, at der med sikkerhed kan peges på ét karakteristikum, nemlig idéen om kulturrelativisme (siden Meinecke også gerne kaldet individualitetsidéen). ${ }^{7}$ Som led i historismens opgør med oplysningen er det accepteret, at sidstnævntes universalisme og udprægede kosmopolitisme anfægtes til fordel for det standpunkt, at én kultur ikke kan måles med en andens målestok; ${ }^{8}$ en holdning, der ofte illustreres med Rankes formulering om, at hver kultur er „unmittelbar zu Gott“. ${ }^{9}$ Denne relativering indeholder en spatial såvel som en temporal dimension: Man må afholde sig fra at overføre moralske og æstetiske kriterier både på fortidigt og samtidigt eksisterende kulturer. Disse to aspekter af relativismen finder imidlertid vidt forskellige udtryksformer igennem historismens udvikling og relaterer sig til sociale, politiske og videnskabelige spørgsmål på lige så forskellige måder.

\section{Historisme som klassicisme og historiefilosofi}

Selv i den sparsomme danske forskning kan uenigheden om dateringen af historismens begyndelse findes. Må man tilbage til det 18. århundrede, eller ej? Som eksempel skriver Bernard Eric Jensen, ${ }^{10}$ som har forfattet kapitlet om historisme i bogen Humanistisk Videnskabsteori: „Historismen blev etableret som humanvidenskabelig forskningstradition i løbet af første halvdel af 1800-tallet." ${ }^{11}$ Histo-

6 Rüsen 1993, s. 17.

7 Jeg anvender begrebet kulturrelativisme uden nogen pejorativ ladning; simpelthen som betegnelsen for den idé, at enhver kultur kun kan forstås og dømmes ud fra sine egne standarter, og aldrig fra en anden kulturs.

8 Som med alle generaliserende udsagn, kan der nævnes enkelte marginale undtagelser, så som Beiser, der i sit historismeværk påpeger, hvordan Humboldt i dele af sit forfatterskab udtrykte sympatier for oplysningens universelle naturretstanke, selvom han samtidig eksplicit plæderede for idéen om nationers særegenhed (Beiser, 2015, s. 167-214).

9 Ranke 1971, s. 60.

10 Et andet eksempel fra den danske litteratur (også her fra en videnskabsteoretisk grundbog), hvori en lignende historisk afgrænsning kan findes, er Søren Kjørups kapitel om historismen i andet bind af sin Menneskevidenskaberne - Humanistiske forskningstraditioner. Kjørup beskriver historismen som „først og fremmest udfoldende sig i Tyskland i anden halvdel af 1800-tallet“ (Kjørup, 2008, s. 85). 
rismen knyttes altså først og fremmest til historieskrivningen, dens institutionalisering og disciplinering. Som kontrast opererer Hans-Jørgen Schanz med både en „filosofisk“ og en „historiografisk“ historisme, hvormed man må forstå, at de samme grundlæggende idéer får udtryk i to forskellige tekstgenrer. ${ }^{12}$ Fokuspunktet for dette afsnit er det, Schanz kalder den filosofiske historisme.

Navnlig Herders filosofi opstilles ofte som historismens første artikulation og som det sted, hvor kulturrelativismetanken for alvor blev indført i det tyske åndsliv. En sådan indstilling viser sig hos den engelske idéhistoriker Isaiah Berlin, der betegner Herder som ,the father of the related notions of nationalism, historicism, and the Volksgeist ". ${ }^{13}$ Ifølge Berlin introducerer Herder tre grundlæggende nye idéer omkring historien. ${ }^{14}$ Jeg parafraserer:

- Populisme. En idé om et folks fælles kulturelle identitet, der ikke er knyttet til den politiske orden. Der er således ikke tale om en nationalistisk populisme, hvor stat eller monark besynges, men snarere en folkeånd, som ethvert medlem af en befolkning deltager i.

- Ekspressionisme (ikke at forveksle med den senere kunstretning). Forestillingen om, at alle en kulturs udtryk og frembringelser, i særdeleshed indenfor kunstarterne, manifesterer hele kulturens „personlighed“, på samme måde som individets frembringelser efter samme logik eksternaliserer dette individs indre væsen. Alle frembringelser er således former for kommunikation, der tilvejebringer den fælles forståelse og det umiddelbare fælles tilhørsforhold, som Herder mener præger en befolkning (jf. populismebegrebet).

- Pluralisme. Dette begreb, der var centralt for historismen generelt, hævder, at der ikke findes én rigtig samfundsform, lige så lidt som én sund kultur eller ét sandt sprog. Flere kulturer kan sameksistere med lige ret, og kultiveres ikke ved andre kulturers indgreb, men alene ved immanent udvikling (jf. ekspressionismebegrebet).

Herder anlægger således et holistisk perspektiv indenfor den enkelte kultur og et relativistisk perspektiv på forholdet mellem kulturer. I Herders filosofi udlægges det, der skulle blive et historieteoretisk aksiom for den senere historieskrivning i det 19. århundrede: historiens gang må undersøges indenfor rammerne af enkelte kulturers udvikling og enkelte folks særegenheder. Samtidig hører Herder til blandt kernefigurerne i den tyske nyhumanistiske tradition, hvis fremmeste kendetegn er en normativ nyklassicisme og et græcitetssværmeri (ikke sjældent udmøntende sig i den teutonsk-hellenske idé om et åndeligt slægtskab mellem den antikt græske og den tyske folkeånd). Hvordan sameksisterer disse to tankeparadigmer; det nyhumanistisk-klassicistiske, der ophøjer antikken, og det histori-

\footnotetext{
12 Schanz 1996, s. 20.

13 Berlin 1976, s. 145.

14 Berlin 1967, s. 153.
} 
stisk-kulturrelativistiske, der vil se enhver kultur for sig? Disse to tilsyneladende kontradiktoriske idéer var tæt sammenvævede i det sene 18. århundredes tyske tænkning, og den kulturrelativistiske historieforståelse kan ligefrem siges at have fået en tidlig formulering, endog før Herder, hos Johann J. Winckelmann, den tyske tænker, der i allerhøjeste grad identificeres med nyklassicisme. Selve begrebet historisme har, så vidt vides, sin første anvendelse hos Friedrich Schlegel, der med det betegner Winckelmanns kulturforståelse. Denne forståelse består, ifølge Schlegels udlægning, i, at der imellem kulturer skulle bestå en ,umålelig forskel“. ${ }^{15}$ Også den store tyske filolog Ulrich von Wilamowitz-Moellendorff, der regnes for en af de fremtrædende repræsentanter for den historistiske tilgang til studiet af antikken, og som i sen alder vedkendte sig betegnelsen historisme, ${ }^{16}$ identificerer Winckelmann som den tænker, der viste ,,wie auch ästhetische Würdigung allein aus den Anschauung der Zeit, in welcher das Kunstwerk entstand, aus dem Geiste des Volkes, das es hervorbrachte, möglich sei“. ${ }^{17}$ I dette citat fremhæves Winckelmanns bidrag til en (æstetisk) kulturrelativisme og en kontekstualistisk kunsthistorie, der danner grundlag for Wilamowitz' egen filologiske selvforståelse. Wilamowitz' historisme trækker således på det aspekt af Winckelmanns tænkning, der betragter antikken ud fra det individualitetsprincip, som sidenhen skulle blive den generelle historiske betragtningsmåde i historismen. Hvad angår denne kultur- og kontekstforståelse hos Winckelmann, kommer imidlertid et paradoks til udtryk, som er illustrativt for den ovenfor nævnte paradoksalitet i den nyhumanistiske sammenstilling af historisering og klassicisme: Winckelmann mente ganske rigtigt, at den græske kunst var uadskilleligt forbundet til det græske klima og det perikleiske demokrati - det græske Gesamtleben, som Meinecke kalder det, ${ }^{18}$ men insisterede samtidig på, at samme kunst måtte imiteres og genrejses af tyskerne. ${ }^{19}$

Dette paradoks er ofte blevet bemærket i både Winckelmann- og historismeforskningen, hvor blandt andre den tyske hermeneutiker Hans-Georg Gadamer, der finder historismens begyndelse hos både Winckelmann og Herder, ${ }^{20}$ ser en spænding mellem klassicismen og den historiske fornuft, der udviklede sig indenfor klassicismen: „Begrebet 'klassisk' eller 'klassisk oldtid' (...) forenede (...) en normativ og en historisk side““. ${ }^{21}$ Denne spænding forbliver ifølge Gadamer uforløst indtil G.W.F. Hegel, hos hvem sameksistensen af det klassiske og det historiske bliver „,systematisk retfærdiggjort“ ved, at det klassiske tilføjes en „,be-

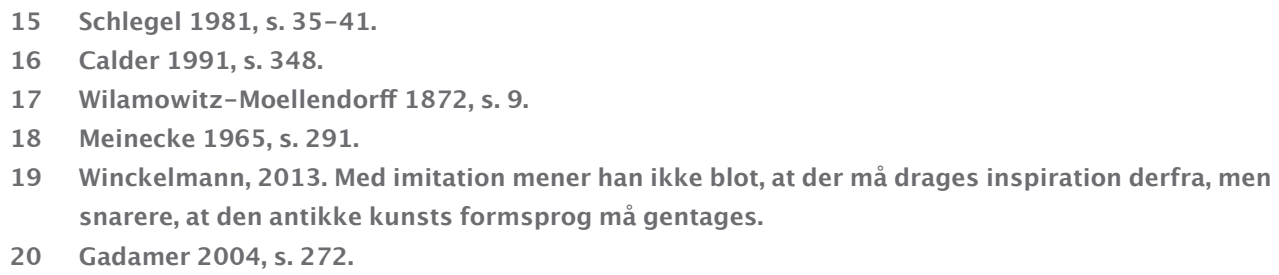


tinget forbilledlighed“. ${ }^{22}$ Andre udlægninger vil insistere på, at historiseringen og klassicismen allerede var teoretisk komplementære hos tænkere som Herder og Wilhelm von Humboldt, der begge forfægtede antikkens forbilledlighed, men uden Winckelmanns insisteren på imitation. Hyppigt henvises der til den nyhumanistiske pædagogik som det sted, hvor det antikke Vorbild forenedes med den kulturspecifikke Bildung. Alt andet lige forårsager den vedholdende sameksistens af klassicisme og kulturrelativisme, at man må operere med et historismebegreb, der ikke ser disse to idéer som gensidigt udelukkende, hvis altså historismen skal føres tilbage til perioden fra Winckelmann til Humboldt.

Meinecke selv finder utvetydigt historismens begyndelse og storhedstid i denne periode. Udover en afsluttende mindetale til Ranke, bevæger hele hans Die Etstehung des Historismus sig ligefrem udelukkende i den historiske tænkning før 1800. I bogens forbemærkning formuleres et historismebegreb, der deler væsentlige træk med det, Berlin senere skulle beskrive som ekspressionisme: „Historismus ist eben zunächst nichts anderes als die Anwendung der in der grossen deutschen Bewegung von Leibniz bis zu Goethes Tode gewonnenen neuen Lebensprinzipien auf das geschichtliche Leben.“23 Det væsentligt nye i dette tidligt-historistiske tankegods er ifølge Meinecke opløsningen af naturretstanken. Dette anskues af ham som et ønskværdigt bortfald, eftersom den kulturelle individualitet først kunne komme til sin ret hinsides naturrettens abstrakte universalitet. ${ }^{24}$ Meinecke dedikerer i værket 140 sider til en analyse af Goethe, der sidenhen sjældent er blevet indlemmet i den historistiske kanon. Han insisterer på, at Goethes dels poetiske dels videnskabelige helhedsforståelse af naturen og historien stillede et nyt perspektiv til rådighed, som muliggjorde ,einer tieferen und lebensreicheren Geschichtsbehandlung“. ${ }^{25}$ Historismeforskeren Georg G. Iggers retter kritik mod denne rekurs til nyhumanismen hos Meinecke:26

„Going back to the neo-Platonism²7 of the German classical period, particularly to Goethe, Meinecke sought to overcome the relativism of historicism in an ethereal world of culture in which politics, which had occupied an important place in his earlier history of ideas, now seemed no longer

22 Ibid.

23 Meinecke 1965, s. 2.

24 Ibid. Desangående må det påpeges, at Frederick C. Beiser i sit historismeværk kraftigt har nuanceret idéen om historismen og naturretten som gensidigt udelukkende, da han påpeger, at både Herders og Humboldts filosofier indeholdte former for naturretstænkning (Beiser, 2015, s. 12-13, 156).

25 Meinecke 1965, s. 505.

26 Modsat finder Erich Auerbach, at Meineckes værk er „the finest and most mature treatment [af historismen] I know" (Auerbach, 2013, s. 444).

27 Med „neo-Platonism“ tilsigtes der, ifølge min læsning, blot en generel ringeagt for den materielle realitet til fordel for en åndelig og i større eller mindre grad mystisk virkelighedsdimension. 
to matter after his disappointment with the course of twentieth-century history. "28

Mistanken overfor politik, som Iggers her peger på hos Meinecke, var et gennemgående træk i den nyhumanistiske tænkning. Hos Herder var nationen utvetydigt begrebet apolitisk; der var snarere tale om en kulturel, eller ligefrem metafysisk, enhed, end et fællesskab beroende på politiske institutioner. Dette er blevet påpeget gentagne gange af forfattere (som Isaiah Berlin), der ønsker at rense Herder for den anakronistiske anklage, at han skulle være fortaler for en politisk nationalchauvinisme. Den nyhumanistiske Volksgeist-idé var som historisk tydningsprincip (jf. ekspressionismetanken) rodfæstet i idéen om den organiske og ureglementerede kulturelle udfoldelse. Denne forestilling medførte som konsekvens, at staten som institution (og måske ligefrem politik overhovedet) måtte betragtes som et invasivt fremmedlegeme. ${ }^{29}$ Således synes Iggers diagnose af, at en ,ethereal world of culture“ fungerede som et værn mod absolut relativisme, i hvert fald at være gældende for de tænkere, som Meinecke fremhæver som historismens grundlæggere (selvom dette dog ikke skal forstås som medførende nogen politisk resignation eller tilbagetrukkenhed, hvilket navnlig Humboldts eget politiske virke viser). Jeg mener, at det er her, angående forholdet til politik, at den mest markante indholdsmæssige diskontinuitet i den historistiske tradition mellem det 18. og 19. århundrede kan findes. At betragte staten som underordnet ift. historiens naturlige udfoldelsesproces står i markant kontrast til den senere, historievidenskabelige historisme, der, rundet af den hegelske idealisme, i højere grad var tilbøjelig til at se staten som åndens topmål og som „hovedaktør på historiens skueplads". ${ }^{30}$

I det omfang, man finder historismens udspring i det 18. århundrede, må man derfor samtidig acceptere, at den historistiske tradition foretog en grundlæggende re-orientering i sit teoretiske forhold til staten. Dette divergenspunkt mellem historismen før og efter Ranke er, som allerede indikeret med Schanz, ledsaget af en forandring i historismens foretrukne genre. Efter Ranke blev et centralt element i udformningen af historieskrivningens selvforståelse at lægge distance til historiefilosofiens spekulation. Dette betyder imidlertid ingenlunde, at historiefilosofiske idéer hentet fra tænkere som Herder og Humboldt ikke spillede en strukturerende rolle i historieskrivningen (hvilket jeg vil se nærmere på i artiklens sidste hovedafsnit). Det er ikke kontroversielt, at der består en vis kontinuitet mellem de to genrer, der bl.a. begge betjener sig af kulturrelativismeidéen, organismemetaforen samt brugen af en række fælles grundbegreber. Jeg mener derfor, at spørgsmålet om, hvorvidt nyhumanisterne skal forstås som en integreret del af historis-

28 Iggers 1995, s. 153.

29 Korsgaard 2004, s. 133-141.

30 Mordhorst og Møller 2005, s. 31. 
men, eller blot som et forstadie, ikke så meget peger på en substantiel uenighed i litteraturen, men snarere en forskel i analytisk præference. Anlægger man som udgangspunkt en politisk-idéhistorisk eller videnskabshistorisk synsvinkel, vil omvurderingen af staten og det tekstuelle genreskifte være naturlige steder at lægge et periodisk snit. Derimod ville et perspektiv, der afsøger de filosofiske eller teoretiske idéer, finde større kontinuitet. Jeg vil i de næste to afsnit undersøge netop det politiske og det videnskabshistoriske perspektiv.

\section{Historisme som politisk historieskrivning}

Mener man, at historismen begyndte i det 19. århundrede, vil man næsten med sikkerhed opstille Ranke som traditionens fader. At antage Ranke, det nok mest konstante medlem af den historistiske kanon, som ,the historist par excellence ${ }^{\text {‘31 }}$ eller som „der erste grosse Vertreter des Historismus“32 indebærer en bestemt forventning angående historismens generelle tematiske indhold. Ligesom det er nærliggende at tolke historismen ud fra en ekspressionistisk kulturidé, når man finder Herder som traditionens begyndelse, på samme måde vil det at begynde hos Ranke nødvendigvis lede blikket mod idéen om staten og refleksioner over dennes rolle i den historiske dynamik. Ranke giver eksplicit udtryk for sin opfattelse af staten som den centrale historiske aktør og som en legemliggørelse af den historiske fornuft i tekster som „Die grossen Mächte“ og „Politisches Gespräch“33, og selv bliver han i 1841 officielt den preussiske stats historiker, hvormed historieskrivningen allierer sig med den regerende statsmagt på en måde, hvis lige ikke kan findes i det 18. århundredes historiske tænkning. Jörn Rüsen påpeger, hvordan opskrivningen af staten fik væsentlig indflydelse for det analytiske blik, Ranke anlagde i sine empiriske studier: hvor det brede folks handlinger beskrives som blinde og arbitrære, tolkes statens (dvs. fremtrædende statsmænds, diplomaters og militærpersonligheders) som reflekterede og som værende i overensstemmelse med historiens fornuftige udvikling. ${ }^{34}$ Også Iggers understreger i forordet til sin engelske Ranke-oversættelse, at „Ranke nowhere acknowledged the rights of the individual against the state, which Humboldt and Haller had defended from opposing political positions. "35 Ranke forfægtede dog ikke en nødvendig trældom hos individet, skal man forstå, men indlemmede snarere staten i historiens bestandige realisering af friheden. Dette medfører, at

\footnotetext{
31 White 2014, s. 140.

32 Jaeger og Rüsen 1992, s. 73.

33 I denne tekst forstår Ranke krigen som en historisk drivkraft, hvis udfald altid vil favorisere den mest moralske stat, eftersom den stat, der er sundest indadtil, også vil være stærkest udadtil.

34 Rüsen 2005 , s. 49.

35 Iggers 2011, s. XXI.
} 
den nyhumanistiske frihedsidé nu stilles til revurdering; en revurdering, der ikke kan tilbageføres til Ranke alene, men som reflekterer en generel politisk mentalitetsændring efter Napoleonstiden. Litteraturforskeren Anna Sandberg bemærker, hvordan det, hun kalder det 19. århundredes antirevolutionære frihedsbegreb, må betragtes som en ,frihed til staten, til at indgå i og yde sin pligt for fællesskabet“ modsat det franske revolutionære kald til „frihed fra staten“ (som også den tyske nyhumanisme var præget af). ${ }^{36}$ Besyngelsen af staten er også blevet påpeget hos den centrale danske historist Caspar Paludan-Müller, for hvem „Staten alt mere og mere gaaer op for den Enkeltes Bevidsthed som en Totalitet, giennem hvis Toppunkt det Heles fornuftige Villie skal komme til Virkelighed“. ${ }^{37}$

Med denne omvending i vurderingen af staten åbnedes et nyt mulighedsrum for historieskrivningens rolle i det politiske felt, og et mangefacetteret forhold mellem samtidspolitik og historieskrivning trådte frem, der ingenlunde blot handlede om den teoretiske vurdering af staten som abstraktum. Fra den socialhistoriske metodes udbredelse i det 20. århundrede, er historismens tankegods i stigende grad blevet analyseret i forhold til de relevante aktørers sociale placering. Således er det 19. århundredes historister blevet identificeret med et specifikt klasseperspektiv, nemlig dannelsesborgerskabets. Iggers hovedværk, The German Conception of History, har været instrumentelt i at fremskrive netop denne forbindelse. ${ }^{38}$

Selvom dannelsesborgerskabet udgør den dominerende sociale baggrund for historismen i det 19. århundrede, lader det sig imidlertid ikke gøre dermed at føre den nye samtidspolitiske valens, der i dette århundredes historiske tænkning opstod, tilbage til et entydigt kompleks af klasseinteresser. En nuancering er nødvendig. Navnlig en bestemt idéhistorisk sondring er her blevet udbredt i forskningen mellem på den ene side den politisk konservative historisme, der har Ranke og siden Georg Waitz som frontfigurer, og på den anden side den preussisk-lilletyske (preussisch-kleindeutsche) skole (kaldet sådan på grund af det fælles ønske om en tysk samling under preussisk ledelse og med udeladelse af Østrig), hvor Droysen, Mommsen, Sybel og Treitschke er hovedpersonerne. Førstnævnte var dominerende i den tyske Vormärz-periode, dvs. til revolutionsåret 1848, hvorefter sidstnævnte, der i langt højere grad var del af det liberaltnationalistiske projekt, blev mere fremtrædende i det historiefaglige miljø. Disse

36 Sandberg og Siegfried 2014, s. 52.

37 Paludan-Müller citeret fra: Mordhorst og Møller 2005, s. 138.

38 Rüsen og Jaeger har dertil vist, hvordan selv de tidlige faser af borgerskabets sociale opstigning $\mathrm{i}$ det 18. århundredes oplysningstid formede centrale tanker, der skulle bane vejen for historismen - herunder navnlig den skotske oplysnings universalhistorie (Rüsen og Jaeger, 1992, s. 12-13). Denne opdagelse er led i en generel opblødning i forskningen af idéen om et skarpt skel mellem oplysning og historisme. For et andet væsentligt værk indenfor dette tema, se: Hans Peter Reill: German Enlightenment and the Rise of Historicism. 
to skoler, der begge indoptog idéen om staten som central historisk kraft, er blevet fremhævet som to distinkte måder at politisere historieskrivningen.

Et tværgående tema i litteraturen omkring den første, konservative periode er reaktionen mod den franske revolution. Desangående taler Rüsen om historieskrivningen som et svar på en „Orientierungskrise in der intellektuellen Elite der führenden europäischen Gesellschaften“ i begyndelsen af det 19. århundrede. ${ }^{39}$ Med en høj grad af indflydelse fra den engelske Edmund Burkes konservatisme, betonede denne skole den historiske kontinuitet til fordel for revolution. Den historiske viden og dannelse skulle tjene til at vejlede en tempereret politisk styring uden pludselige og drastiske handlinger, så at fremtiden ikke brød med den af fortiden udstukne retning. Jeg skal vende tilbage til forholdet mellem historieskrivning og konservativisme hos Ranke-skolen i artiklens næste afsnit.

Hvor den franske revolution stadig var et referencepunkt for den preussisk-lilletyske skoletolkes denne imidlertid primært ud fra en anden historisk erfaring: det liberale nederlag efter revolutionsåret. ${ }^{40}$ Historien bliver nu i højere grad forstået som en magtkamp. ${ }^{41}$ Navnlig historisten Heinrick von Treitscke endte med at få enorm indflydelse under Bismarck samt under den efterfølgende wilhelminske tid, og hans aggressivt nationalistiske og åbent antisemitiske historieforståelse er blevet tolket som et markant skridt på vejen mod det, der skulle blive den nationalsocialistiske ideologi. ${ }^{42}$ Den preussiske skole politiserede meget eksplicit historieskrivningen - Droysen beskrev hånligt Ranke-skolen som „eunukagtige“ historikere ${ }^{43}$ og de kombinerede dertil hyppigt det historiefaglige virke med et praktisk politisk engagement. Hos aktørerne i denne skole betingede disse ligefrem hinanden: lødig historisk forskning forudsatte en aktiv stillingtagen til de verserende politiske spørgsmål. Objektivitet blev ikke højagtet mindre end hos Ranke-skolen, men objektivitet var nu ikke længere betinget af Unparteilichkeit, hvilket kommer til udtryk i Droysens begreb om „objektive Parteilichkeit“. ${ }^{44}$ Denne historistiske skole betragtes typisk ud fra den indfaldsvinkel, der afsøger de historistiske tænkeres konkrete politiske ønsker reflekteret i de historiske værker, samt deres måde at gøre krav på politisk indflydelse for historieskrivningen.

Hvor jeg ovenfor har nævnt de to centrale historiske erfaringer, som historismen i sin reception er blevet tolket ud fra, må det også påpeges, at receptionen selv i høj grad blev formet af ekstra-videnskabelige fænomener, navnlig de to verdenskrige, der bidrog til udhulingen af adskillige af de idéer, der havde været

39 Rüsen 1993, s. 21.

40 Jaeger og Rüsen 1992, s. 91 . Ranke selv levede ganske vist til 1886, og nåede derfor at opleve både revolutionsåret og den tyske samling. Men, som Hayden White påpeger, havde disse ydre begivenheder forsvindende lille indflydelse på ham (White, 2014, s. 164).

41 Ibid.

42 Hawes 2019, s. 117-120.

43 Droysen 1977, s. 236.

44 Droysen citeret fra: Jaeger og Rüsen 1992, s. 90. 
grundlæggende i historismen - ikke mindst idéen om staten som en etisk kraft og den rankeianske idé om krigen som den historiske fornufts motor - og derudover til at genrejse behovet for universelle fornuftsidéer hos mange tænkere. Leo Strauss tilbyder en læsning af historismen, der tydeligt er filtreret igennem krigenes traumer. Strauss anvender ikke den ovennævnte sondring mellem en konservativ og en liberal-nationalistisk periode, men begriber snarere hele historismen som en radikal modoplysningsbevægelse (og forfægter derfor en stærkt dikotomisk sondring mellem oplysning og historisme). Han mener, at den franske revolution motiverede historisterne til at fremtænke en ny historieteori, der ville diskreditere naturretstanken. ${ }^{45}$ Han skriver, at ,the founders of the historical school seemed to have realized somehow that the acceptance of any universal or abstract principles has necessarily a revolutionary, disturbing, unsettling effect as far as thought is concerned“". ${ }^{46}$ For Strauss blev historismen således intentionelt fremtænkt med henblik på at delegitimere enhver idé, der kunne tjene som rettesnor for samfundsmæssig forandring. Denne diagnose repræsenterer et (yderliggående) eksempel på en strømning i historismereceptionen, der ønskede at rehabilitere oplysningens idealer, og så historismen som det historiske levn, der udgjorde den største hindring. ${ }^{47}$

\section{Historisme som Wissenschaft og fremstillingsform}

Jeg har nu gennemgået historismen betragtet ud fra dens filosofiske grundlagsidéer og dens politisk-sociale kontekst. Dette sidste hovedafsnit omhandler dens videnskabelige status, da dette er et centralt fokuspunkt i forsøg på at karakterisere historismen. Således skriver Rüsen, at „,'Verwissenschaftlichung' einen plausiblen Gesichtspunkt abgibt, unter dem man die Entwicklung des historischen Denkens von der Aufklärung zum Historismus interpretieren kann. "48 Hermed finder han i videnskabeliggørelsen et sandsynligt svar på det prekære spørgsmål om, hvor oplysningens historietænkning ender og historismen begynder. Når historismen forbindes med historiens videnskabeliggørelse, gælder det grundlæggende på to områder. For det første cementerede de historistiske tænkere en historiefaglig selvbevidsthed, der drejer sig om en metodisering af de historiske erkendelses- og udlægningspraksisser, så at den enkelte historiker indtræder i et felt af allerede etablerede fremgangsmåder, der sikrer lødigheden af arbejdet.

45 Strauss nævner ingen konkrete historistiske tænkere, men fremstiller snarere „historicism“ som en anonym og homogen kraft. Han taler også om „the historical school“, som oftest betegner den historikertradition, der fødtes med Ranke og dennes umiddelbare arvtagere som Georg Waitz. Om det imidlertid er denne tradition, Strauss refererer til, er uvist. 
Dernæst bliver historiefaget i løbet af første tredjedel af det 19. århundrede endegyldigt etableret som en disciplin i egen ret på universiteterne. Med disse to bevægelser bliver historieskrivningen definitivt afgrænset fra dilettantisme og anden 'ukvalificeret' omgang med historien.

Tre tænkere synes at have forrang, når der tales om historismen som videnskabeliggørelsesproces. Disse er Humboldt (navnlig hans tekst fra 1821 „Über die Aufgabe des Geschichtsschreibers"), Ranke (hvis metoderefleksioner og -kritik i „Zur Kritik neuerer Geschichtsschreiber“ fra 1824 er specielt fremtrædende) og Droysen (hvis Historik, udgivet i 1857, betragtes som en milepæl i artikulationen af historievidenskabens teoretiske og epistemologiske grundlag). For indeværende skal jeg holde mig til Ranke, med henblik på at tydeliggøre forbindelsen mellem den videnskabeliggørelsesproces, som han anses som central i, og det konservative standpunkt, som han og hans efterfølgere er blevet taget til indtægt for.

Rankes historievidenskabelige position opsummeres prægnant i det citat fra indledningen til hans Geschichten, der uden tvivl er den mest citerede passus i hele litteraturen omkring historismen: „Man hat der Historie das Amt, die Vergangenheit zu richten, die Mitwelt zum Nutzen zukünftiger Jahre zu belehren, beigemessen; so hoher Ämter unterwindet sich gegenwärtiger Versuch nicht: er will bloss zeigen, wie es eigentlich gewesen. “49 Denne passage, hvori Ranke distancerer sig fra det, der typisk kaldes eksemplarisk historie (historie skrevet med henblik på fortidens forbilledlighed og normativitet), ${ }^{50}$ fremdrages stort set uden undtagelse, når Rankes bidrag til historieskrivningens videnskabeliggørelse skal behandles. At netop dette citat bliver betragtet som repræsentativt for Rankes nybrud i den historiske tænkning viser, at det, som Ranke bidrager med, ikke er en radikalt ny metode - den kritiske metode havde da også allerede længe været praktiseret, navnlig i filologien, da Ranke i 1824 skriver dette værk - men snarere nye indstillinger til historiens fremstilling og dennes normative implikationer. Af denne årsag fokuserer forskningen i historiens videnskabeliggørelse generelt også hyppigt på selve den tekstuelle fremstilling, snarere end det kildearbejde, der går forud for denne. Et tilbagevendende tema desangående er, at bestemte valg i fremstilling medfører bestemte politiske implikationer. Navnlig to tænkere har udviklet omfattende systematiske teorimodeller - af begge betegnet ,typologier“ - omkring denne forbindelse: Jörn Rüsen og Hayden White. ${ }^{51}$ Begge er de enige om, at Rankes fortælleform både muliggør historiens videnskabeliggørelse og prædisponerer den til konservativisme. Jeg vil her se på White.

White introducerer i sit hovedværk Metahistory en original, litteraturvidenskabeligt inspireret historieteori, der retter sig mod historiske teksters retoriske, stilistiske og narrative muligheder. En lige så original læsning af historismen er at

49 Ranke 1885 , s. VII.

50 Assis 2014, s. 1-4.

51 Rüsen 2005, White 2014. 
finde blandt de eksempler, White i værket gennemgår for at konkretisere sin teori. Ranke (som White ser som historismens ubestridte hovedperson) fremdrages som eksemplet på den narrativistiske genre, som White kalder komedie. Dertil benytter Ranke ifølge White en organicistisk forklaringsmodel samt en synekdokisk og metaforisk stil. ${ }^{52}$ Komedie betegner her en form for narrativ, hvori intet er udleveret til arbitrære tilfælde og blind kontingens, og hvor fortællingen ender i en forsoning af konflikter. Den organicistiske model påpeger en prioritering af kontinuitet over brudvis udvikling (og angiver således et typologisk træk, som Ranke deler med Herder). Sluttelig dækker metafor og synekdoke hhv. en ,interest in events in their particularity and uniqueness“ og en brug af del-helhed-modeller i fortællestrukturen. ${ }^{53}$ Det er den „metaforiske“ troskab mod de enkelte kilder, der lod Ranke blive modtaget som en bastion for saglig historieskrivning i sin samtid. Ved at (hævde at) udfylde narrativet med sagsforhold, der lader sig føre tilbage til kildemateriale, distancerede Ranke og hans arvtagere sig fra historiefilosofien, den eksemplariske historieskrivning samt den form for spekulativ (for)historieskrivning, der var udpræget i oplysningen, og som siden Dugald Steward er kendt under betegnelsen „,conjectural history“ (herunder forestillinger om menneskets naturtilstand). Det væsentlige i denne sammenhæng er imidlertid af hæfte sig ved selve forudsætningerne for at formidle kildemateriale narrativisk - for Ranke opgav aldrig fortællingen til fordel for den blotte annalistik, hvor årsagssammenhænge udelades.

Her må perspektivet rettes mod det, White udpeger i Rankes brug af synekdoke. Med denne retoriske term forstår White et bestemt historieteoretisk blik, hvor de enkelte begivenheder indholdsbestemmes ud fra en universel fortolkningsramme; en, med Iggers ord, ,,coherence hidden behind the phenomenal world“. ${ }^{54}$ Der er således ifølge White en spænding mellem universelt og konkret indlejres i selve tekstopbygningen hos Ranke. Dette standpunkt indtages også af Mordhorst og Møller, der mener, at formen for Rankes tekster, der på den ene side gjorde et objektivitetskrav gældende i kraft af en erklæret deskriptiv realisme, på den anden side tjente til at udbrede et korpus af implicitte filosofiske og politiske idéer - ,også lang tid efter, at alle havde opgivet den filosofi, der fulgte med mellem linjerne.“"55 I denne forståelse er der altså ingen afgrundsdyb kløft mellem historiefilosofien og den historievidenskabelige historisme. Et holistisk perspektiv, der ikke i sig selv uddrages af kildestudierne, tjente til at sammenkæde de enkelte begivenheder narrativisk. Dette påpeger Møller som et paradoks ved forholdet mellem narrativitet og kildetro realisme i Rankes stil: „Geschichtschreibung, die bloss Begebenheiten und Ereignisse zusammenträgt, seien sie auch noch so wahr,

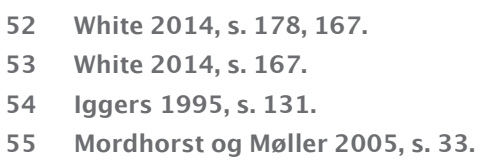


ist genauso sinnlos“ og videre understreger han, med en tilspidset formulering: „Die Geschichte, die Sinn hat, ist nie wahr und vice versa“. ${ }^{56}$ Den sandhed, som Ranke gør krav på, er nødvendigvis (for Møller) kompromitteret af selve det narrativ, som Ranke etablerer for at forlene en enhed mellem helheden og delene. Det er denne konstitutive perspektivisme, som White søger at beskrive. Med sine tekstuelle formbetegnelser udpeger han de faktorer, der præfigurerer det „historiske felt“ (historical field), dvs. forudbestemmer mulige sammenhænge eller „plots“ for historiske begivenheder. ${ }^{57}$ Hver fremstillingstype medimplicerer en forståelse af dynamikken i samfundsmæssig forandring, og derigennem en politisk præference: „Just as every ideology is attended by a specific idea of history and its processes, so too, I maintain, is every idea of history attended by specifically determinable ideological implications. “58 White identificerer fire „,ideologiske positioner" for historieskrivningen: anarkisme, konservatisme, radikalisme og liberalisme. “59 For Rankes vedkommende bestemmer White den ideologiske position som konservativisme, eftersom komedien som overordnet narrativ fremstiller historiens som en proces, der ikke kalder på menneskers intentionelle indgreb. De historiske begivenheders arrangement hos Ranke giver indtrykket af, at man bebor ,the best of possible historical worlds, or at least the best that one can 'realistically' hope for."60 Forholdet til det politiske er således for White konstitutivt for den historistiske tradition, men grundende hertil findes ikke primært i de konkrete, reflekterede idéer, der kan findes i traditionen, men derimod i de formale teksttypologiske træk.

Givet historismens videnskabelige status, ønskede denne at afgrænse sig fra filosofien og (for Ranke-skolens vedkommende) fra den eksplicitte politiske stillingtagen. En analyse som Whites, der borer ned under den selvforståelse, som Ranke og de øvrige historister forsøgte at fremskrive, og blotlægger de mere strukturelle faktorer for teksternes opbygning, tilbyder et perspektiv, hvori alle de tre aspekter af historismen, som jeg i denne artikel har behandlet, kan identificeres som virksomme (dog med teksttypen som den afgørende faktor for White). Også i nyere historismeforskning benyttes ofte analytiske vinkler, der forsøger at fremdrage, hvordan historismen var indflettet i flere idéhistoriske kontekster, end dens repræsentanter eksplicit gav udtryk for.

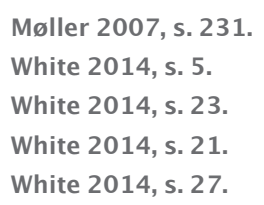




\section{Historismeforskningens aktualitet}

Den tyske historisme er i høj grad et levende forskningsområde på internationalt plan, der stadig frembringer nye indsigter. Et aktuelt blik på historismen, der i de seneste år har vundet frem, bruger termerne ,epistemic virtues“ og „,scholarly personae“ som analytiske begreber, og har herigennem opdaget nye elementer i de selvbeskrivelser, der verserede i det historiefagligemiljø i det 19. århundrede. I et kildestudie af en længere række nekrologer over Ranke-eleven Georg Waitz beskriver historikeren Herman Paul, hvordan et bestemt sæt karakterdyder blev betragtet som betingelser for at kunne fungere som lødig historiker: han afdækker, hvordan det historiske fagmiljø med Ranke og Waitz som forbilleder etablerede uskrevne regler for det, man med et begreb fra sociologen Pierre Bourdieu kunne kalde historikerens habitus. ${ }^{61}$ Omfanget af det analytiske potentiale i denne indfaldsvinkel er blevet anskueliggjort af en gruppe forskere, der i en anden artikel viser, hvordan de pågældende dyder deltog i et bredt udvalg af politiske, religiøse og sociale semantiske felter. ${ }^{62}$ En bestemt karakterdyd taler således ikke alene for historikerens faglige kvalifikationer, men bærer en mængde af normative implikationer med sig. En ny indfaldsvinkel har her åbnet sig for studier af de historistiske tekster og tænkere i relation til deres forskellige samtidige kontekstuelle lag.

\section{Konklusion}

Eftersom historisme er et begreb, der er indført retrospektivt med henblik på analytisk anvendelse, er det en frugtesløs opgave at forsøge at definere en kerne eller en essens for historismen an Sich. Succeskriteriet for en indholdsbestemmelse af historismebegrebet må bero på, hvor dueligt dette er i analytisk sammenhæng, og hvor erkendelsesbefordrende det viser sig når anvendt i konkrete undersøgelser. Det er også, mener jeg, mindre væsentligt at bestemme, om en given tænker er historist, og derimod mere interessant at se på, i hvilket omfang tænkere og værker har bidraget til det historistiske idékompleks.

Jeg mener, at de grundlæggende betydningsforskelle i historismen, forstået som netop idékompleks, uden alvorlige udeladelser kan passes ind på de tre overordnede kategorier, jeg har argumenteret for i artiklen. Disse kategorier angiver perspektiviske variationer, og ikke gensidigt udelukkende fortolkninger. Hvilken variation af begrebet, man finder i en given tekst, afhænger i vidt omfang af, hvilket formål den givne tekst har. Når f.eks. Bernard Eric Jensen fokuserer

61 Paul 2018.

62 Creyghton et.al. 2016. 
på historieskrivningens videnskabeliggørelse, finder dette (i hvert fald delvist) sin årsag i, at hans tekst er skrevet til værket Humanistisk Videnskabsteori, og derfor er videnskabshistorisk anlagt. Når tænkere som Isaiah Berlin fokuserer på det filosofiske indhold, hænger dette sammen med, at hans ekspertiseområde er filosofien og filosofihistorien. At White fremhæver den konservative tilbøjelighed som en konsekvens af den tekstuelle form, må det ses i lyset af hans litteraturvidenskabelige udgangspunkt. Dette skal på ingen måde underminere lødigheden af nogen af forskernes resultater eller antyde, at ethvert perspektiv på historismen kan reduceres til at være en refleksion af det faglige udgangspunkt hos forskeren. Det skal snarere vise, hvor perspektivbundet et begreb, der er tale om. Af netop denne årsag mener jeg også, at en reflekteret bevidsthed om, hvilket område ens forståelse primært er orienteret ud fra, når man benytter begrebet historisme, vil tilføre analyser en væsentlig klarhed, givet begrebets ellers så diffuse natur.

\section{Litteraturliste}

Assis, Arthur Alfaix 2014: What is History for? - Johan Gustav Droysen and the Functions of Historiography. Berghahn Books, Oxford.

Auerbach, Erich 2013 [1953]: Mimesis - The Representation of Reality in

Western Literature. Princeton University Press, Princeton og Oxford.

Beiser, Frederick 2015 [2011]: The German Historicist Tradition. Oxford

University Press, Oxford.

Berlin, Isaiah 1980 [1976]: Vico and Herder - Two Studies in the History of Ideas. Chatto \& Windus, London.

Calder, William 1991: „How did Ulrich von Wilamowitz-Moellendorff read a

Text? The Classical Journal 86. Classical Association of the Middle West and South, Chicago.

Creyghton, Camille et.al. 2016: „Virtue language in historical scholarship:

the cases of Georg Waitz, Gabriel Monod and Henri Pirenne“. History of

European Ideas, 42:7, 924-936. Routledge, Abingdon-on-Thames.

Droysen, Johann Gustav 1977 [1857]: Historik. Historisch-Kritische Ausgabe.

Stuttgard/Bad Cannstatt: P. Leyh.

Gadamer, Hans-Georg 2004 [1960]: Sandhed og Metode. Systime Academic, Århus.

Hawes, James 2019 [2017]: The Shortest History of Germany. The Experiment, New York.

Humboldt, Wilhelm 1946 [1821]: „Über die Aufgabe des Geschichtsschreibers“. Meiner, Leipzig.

Iggers, Georg G. 1995: The German Conception of History. Wesleyan University Press, Middletown Connecticut. 
Iggers, Georg G. 2011: The Theory and Practice of History. Routledge, New York. Jaeger, Friedrich og Rüsen, Jörn 1992: Geschichte des Historismus. Verlag C.H. Beck, München.

Jensen, Bernard Eric 2003: „Historisme“. Humanistisk Videnskabsteori. Red.:

Collin, F., Køppe, S. DR Multimedie, København.

Kjørup, Søren 2008: Menneskevidenskaberne - 2: Humanistiske forskningstraditioner. 2 udgave. Roskilde Universitetsforlag, Roskilde.

Korsgaard, Ove 2004: Kampen om Folket. Gyldendal, København.

Meinecke, Friedrich 1965 [1936]: Die Etstehung des Historismus. R. Oldenbourg Verlag, München.

Mordhorst. Mads og Møller, Jes Fabricius 2005: Historikeren Caspar PaludanMüler. Museum Tusculanums Forlag, København.

Møller, Jes Fabricius 2007: „Caspar Paludan-Müller - Zur frühen RankeRezeption in Dänemark“. Schule, Universität und Bildung. Verlag Friedrich Pustet, Regensburg.

Paul, Hermann 2018: „The virtues of a good historian in early imperial germany: georg waitz’s contested example“ Modern Intellectual History, 15, 3, s. 681-709, Cambridge University Press, Cambridge.

Ranke, Leopold 2012 [1833]: Die grossen Mächte. Insel Verlag, Leipzig. Ranke, Leopold 1941 [1836]: Politisches Gespräch. Insel Verlag, Leipzig. Ranke, Leopold 1971 [1854]: Über die Epochen der neueren Geschichte. R. Oldenbourg, München.

Ranke, Leopold 1885 [1824]: „Zur Kritik Neuerer Geschichtschreiber“. Geschichte der Romanischen und Germanischen Völker. Duncker \& Humblot, Leipzig.

Reill, Peter Hanns 1975: The German Enlightenment and the Rise of Historicism. University of California Press, Berkeley, Los Angeles, London.

Rüsen, Jörn 2005: History: Narration, Interpretation, Orientation. Berghahn Books, New York.

Rüsen, Jörn 1993: Konfigurationen des Historismus. Suhrkamp, Frankfurt am Main.

Sandberg, Anna og Siegfried, Detlef 2014 [2012]: Tysk Kulturhistorie. 2. Oplag. Gyldendal, Riga.

Schanz, Hans-Jørgen 1996: Det Historiske - Refleksioner over Historie og Metafysik. Forlaget Modtryk, Århus.

Schlegel, Friedrich 1981: Kritische Friedrich-Schlegel-Ausgabe XVI. Paderborg: Schöningh Verlag.

Strauss, Leo 1965 [1953]: Natural Right and History. University of Chicago Press, Chicago \& London.

Troeltsch, Ernst 1922: Der Historismus und seine Probleme i Gesammelte Schriften III. Mohr, Tübingen. 
White, Hayden 2014 [1973]: Metahistory - The Historical Imagination in Nineteenth-Century Europe. John Hopkins University Press, Baltimore. Wilamowitz-Moellendorff, Ulrich 1872: „Zukunftsphilologie!“. Gebrüder Borntraeger, Berlin.

Winckelmann, Johann Joachim 2013 [1756]: Gedanken über die Nachahmung der Griechischen Wercke in der Mahlerei und Bildhauer-Kunst. Reclam Verlag, Stuttgard.

\section{Summary}

\section{What is historicism?}

The German concept of Historismus (in English typically rendered as historicism while the older version, historism, may be more appropriate) contains a high degree of semantic complexity. While there is naturally an overlap (insofar as what is denoted is a certain tradition of historical thought revolving around Germany and involving elements such as cultural relativism, an increased sense of historical contingency and historiographical changes) there is also, as I have attempted to show in this article, a significant degree of diversity regarding the specific ideas which the concept is thought to embrace. In this article, I have sought to clarify the concept of Historismus by establishing three general categories which I believe capture the primary orientations in the use of the concepts. By doing this I aim to explicate the contextual dependency of the concept: the meaning assigned to it is generally highly influenced by the analytical aims towards which it is used. An authoritative definition can therefore only be established on a high level of generality - especially as the term was rarely used by the thinkers that, in retrospect, are regarded as belonging to the historicist tradition. 